\title{
Poglądy Biskupa Michala Klepacza na sytuację oświatowo-pedagogiczną okresu międzywojennego
}

Postać Biskupa Michała Klepacza była przedstawiana w wielu publikacjach ${ }^{1}$ z racji roli, jaką odegrał w powojennej Polsce jako Biskup Lódzki, a także jako przewodniczący Episkopatu Polski w okresie uwięzienia Prymasa Wyszyńskiego. O jego działalnosci pedagogicznej pisano niewiele ${ }^{2}$ choć on sam $\mathrm{w}$ swoich publikacjach i wypowiedziach wielokrotnie wyrażał troskę o właściwy kształt szkolnictwa polskiego $\mathrm{i}$ ideałów wychowawczych proponowanych młodemu pokoleniu.

Michał Klepacz urodził się 23 lipca 1893 roku we wsi Wola, gmina Czyste, obecnie Warszawa. Rodzicami Jego byli: Stanisław Klepacz pracownik sezonowy oraz Antonina Marianna z Prokopów. Po nauce w szkole elementarnej, ukończył IV Gimnazjum Klasyczne w Warszawie. Studia teologiczne i filozoficzne odbył w Seminarium Duchownym w Kielcach a dokończył w Akademii Petersburskiej. Po święceniach kapłańskich pracował jako prefekt szkół średnich, wykładowca w Seminarium Duchownym, a następnie został pracownikiem naukowym na Uniwersytecie Stefana Batorego w Wilnie. Jako Biskup Lódzki oddany z całą odpowiedzialnością swemu posłannictwu kształtował kulturę intelektualną i duchową osób mu zawierzonych.

Do ostatnich dni życia bliską mu była problematyka pedagogiczna. W ostatnich latach przed śmiercią uczestniczył czynnie w Soborze Watykańskim II. Przez całe zgromadzenie został wybrany członkiem soborowej Komisji do Spraw Seminariów, Studiów i Wychowania Katolickiego.

To wszystko wyznaczało jego misję wychowawcy i pobudziło do wskazania głównych idei pedagogicznych na poszczególnych etapach pracy.

Slownik jezzyka polskiego pojęcie „misja” wyjaśnia jako „odpowiedzialne zadanie do spełnienia, ważne zlecenie do wykonania, posłannictwo". Misja (może być) kulturalna, naukowa, społeczna ${ }^{3}$. Tak rozumiana misja wyjaśnia sens angażowania się Michała Klepacza w zagadnienia pedagogiczne. Była to naturalna konsekwencja jego czynnego uczestniczenia $w$ życiu wielu jednostek i społeczności. Jego szerzenie kultury szeroko rozumianej, zaangażowanie naukowe i społeczne wyrastało $z$ troski o człowieka $\mathrm{i}$ jego duchowy i intelektualny wzrost. Poparte to było rzetelna wiedzą pedagogiczną. Wprawdzie nie studiował nauk pedagogicznych, to jednak w jego twórczości i działalności widać kompetencje i dobrą orientacje we współczesnych kierunkach szkolnictwa i pedagogiki. Jego działalność teoretyczna i praktyczna na polu pedagogiki wynikała $z$ faktu iż „myśl jego stale była skupiona na człowieku"4. Przyglądając się uważnie tej postaci można z całym przekonaniem stwierdzić, że był to pedagog $z$ powolania.

Spuścizna pisarska Michała Klepacza jest bogata ${ }^{5}$. Oprócz prac zwartych, które sq źródłem wiedzy o autorze $\mathrm{i}$ jego ideach, jest wiele przemówień uzupełniających zakres zainteresowań autora Odnajdujemy je w zbiorach Archiwum Archidiecezjalnego w Lodzi, Archiwum Diecezjal-

\footnotetext{
1 Min. Ks. Krzysztof Gruczyński, Biskup Michal Klepacz 1893-1967, Lódź 1993. Humanista - Biskup Michal Klepacz (1893-1967), w: W nurcie zagadnien posoborowych, red. B. Bejze, t. 1, Warszawa 1967. MJ. Kononowicz, Biskup Michal - prolegomena do portretu, Warszawa 1968.

2 Ks. Antoni Just, Michala Klepacza idealy wychowawcze, w: "Lódzkie Studia Teologiczne" 1993. K. Gruczyński, op., cit.

Slownik jezyka polskiego PWN, Warszawa 1979 s. 185.

- Abp Karol Wojtyła, Humanista Bp Michal Klepacz, w: Wnurcie zagadnien posoborowych, Warszawa 1967 t. II, s. 451 .

"S. Ks. K. Gruczyński, Biskup Michal Klepacz..., s. 303-322.
} 
nego w Klelcach i Archiwum Katolickiego Uniwersytetu Lubelskiego. Krytyczna analiza tych tekstów pozwala ukazać myśl autora dojrzewająca wraz z latami i zmieniająca się rzeczywistością społeczno-polityczną, a także z nowymi zadaniami, które przyszło mu podejmować.

Warto pochylić się nad sylwetką Michała Klepacza, pochodzącego z ubogiej podwarszawskiej rodziny robotniczej, który dzięki wielkiej pracy i wrodzonej niejako inteligencji wspina się na szczyty wiedzy i dochodzi do najwyższych stanowisk naukowych i kościelnych.

Początek jego życia przypadł na ostatnie lata kończącego się wieku XIX, a w historii Polski to okres dojrzewania do zrzucenia jarzma niewoli. Idee budzącego się proletariatu, doświadczanego ubóstwem i poczuciem zniewolenia zrosły się z jego młodym życiem. Dom rodziny Klepaczów był jednak zawsze oparty na wartościach chrześcijańskich, dlatego oparł się indoktrynacji politycznej. Wybór stanu kapłańskiego nie był ucieczka od biedy i trudności wynikających z pochodzenia, ale wyborem drogi życiowej, na której można było siebie w pełni zrealizować, służąc z pokorą Bogu i człowiekowi. Czas kapłańskiego dojrzewania przypadający na lata odzyskanej niepodległości, to okres wypełniony pogłębianiem wiedzy i praca wychowawcy młodzieży duchownej i świeckiej. To także okres wielkiego zainteresowania problemami szkolnictwa $\mathrm{i}$ pedagogiki. W tym czasie (1930 r.) pisze dla duchownych książkę pt: „Duchowieństwo wobec nowoczesnych prądów w szkole polskiej"6, a w 1937 roku ukazuje się poszerzona jej wersja, z myślą o świeckich pod nowym tytułem: „Kierunki organizacyjne oraz ideały wychowawcze we współczesnym szkolnictwie polskim"? . Część pierwsza tej książki nosi tytuł: „Kierunki organizacyjne we współczesnym szkolnictwie polskim" i zajmuje się takimi zagadnieniami, jak: organizacją i reformami szkoły, „monopolem szkolnym”, szkołą wyznaniową i bezwyznaniową oraz areligijną, problemem koedukacji, a także związkami nauczycielskimi i ich stosunkiem do religii i duchowieństwa. Natomiast druga część zatytułowana: „Ideały wychowawcze we współczesnym szkolnictwie polskim", podejmuje problematykę potrzeb ideału wychowawczego w procesie nauczania $\mathrm{i}$ wychowania indywidualnego, społecznego, narodowego, państwowego a także religijnego. Autor powołuje się $w$ tej książce na opracowania pedagogiczne polskich i zagranicznych wychowawców i myślicieli.

Podejmując problematykę ideałów wychowawczych Michał Klepacz chciał dać młodemu pokoleniu mocne fundamenty $w$ budowaniu szczęścia osobistego, jak i narodowego. Przypominał, że szkoła ma nie tylko przekazywać wiedzę, ale i wychowywać wszechstronnie, stąd potrzeba kształcenia charakteru stała się najwyższym zadaniem człowieka i jego wychowawcy. Ideał wychowania społecznego (narodowo-państwowego) to dalszy krok w procesie edukacji człowieka. Michał Klepacz przechodzi ze swoja analizą pedagogiczną przez wszystkie liczące się wspólnoty, poczynając od rodziny a na społeczności ludzkiej kończąc. W wychowaniu ogólnoludzkim przestrzegał przed skrajnym pacyfizmem, wyjaśniajac: ,...pamiętać o wychowaniu ogólnoludzkim, ale poprzez narodowość, przez gotowość do obrony swego ducha narodowego, przez zrozumienie wartości innych narodów" 8 . Widział wiele braków w wychowaniu poza religijnym, a podkreślając wartość religijnego zwracał uwage na konieczność reform.

Działalność w szkolnictwie świeckim i duchownym Michała Klepacza przypada na okres kształtującej się II Rzeczpospolitej. Jako prefekt szkół średnich i wykładowca w Seminarium Duchownym w Kielcach starał się nie tylko prowadzić interesująco lekcje czy wykłady, ale poszukiwal wciąż nowych metod wychowawczych, które służyły kształtowaniu ludzi o wysokiej kulturze intelektualnej i moralnej. Podobnie pojmował swoje obowiązki na Uniwersytecie jako

\footnotetext{
- Michał Klepacz ks., Duchowienistwo wobec nowoczesnych prqdów w szkole polskiej, Kielce 1930, s. 1 - 179.

${ }^{7}$ Michał Klepacz ks., Kierunki organizacyjne oraz idealy wychowawcze we wspólczesnym szkolnictwie polskim, Katowice 1937, s. 1-371.

Ibidem, 8. 268.
} 
nauczyciel akademicki. Uważal, że „na każdym przedmiocie można odcisnąć pieczęć wychowania. Szczególnie przedmioty humanistyczne są naładowane potencjalną energią moralną. Trzeba ją tylko wyzwolić przy nauczaniu"?

Lata powojenne zdominowane zostały przez posługe biskupią w diecezji łódzkiej, w Episkopacie Polski i Kościele Powszechnym. I w tym okresie życia pojawiają się działania związane z pedagogicznymi zainteresowaniami Michała Klepacza.

Czas posługiwania biskupiego (1947-1967) to okres, w którym pedagogika chrześcijariska - religijna została zepchnięta na margines życia publicznego przez inne, „słuszne” prądy. Biskup Klepacz w różny sposób starał się głosić i realizować ideały, z których sam wyrósł i które były mu zawsze bliskie. Zagadnienia wychowawcze pedagogiki katolickiej ukazał bardzo wyraziście we wstępie do tłumaczonej przez siebie encykliki papieża Piusa XI „O chrześcijańskim wychowaniu młodzieży”, która ukazała się w 1947 r. Omówił tam kwestį wychowania i samowychowania; wychowania indywidualnego, społecznego i personalistycznego; wychowania areligijnego i religijnego i poruszył sprawę monopolu szkolnego.

We wniosku złożonym w Sekretariacie Soboru Watykańskiego II, zwrócił uwage na wychowanie integralne, w którym istotną rolę odgrywa wiara w Boga. Chociaż każdy aspekt wychowania ma swoją autonomię, swoj̨ wartość i własny charakter, to jednak pełną wartość otrzymuje każdy $z$ nich dopiero wtedy, gdy zawiera w sobie wychowanie religijne i moralne, rozumiane jako wzrastanie $w$ wyznawanym systemie wartości.

Przyglądając się problematyce szkolnictwa i ideałom pedagogicznym okresu międzywojennego, nie można pominąć działań Michała Klepacza, który wpisał się mocno w plejadę wybitnych pedagogów chrześcijańskich. Był jednym z twórców pedagogiki religijnej. Jego poglądy związane z organizacją szkolnictwa w powstających strukturach odnowionego państwa polskiego miały ściśle patriotyczny charakter. Chciał wnieść swój wkład do rozwoju szkoły polskiej, opartej na mocnych i trwałych fundamentach pedagogiki chrześcijańskiej. Polemizując z poglądami niektórych środowisk potrafił zawsze przedkładać ducha dialogu przed nietolerancyjną agresję. $\mathrm{Z}$ dużym uznaniem odnosił się też do osiągnięć pedagogów niekatolickich, np. F.W. Foerstera, z którego dorobku naukowego chętnie czerpał inspirację do własnych przemyśleń. Nie tylko pisał o tolerancji, ale był tolerancyjny. Szczególny nacisk w swojej działalności piśmienniczej stawiał na szkołę wyznaniową, w której cała społeczność szkolna, nauczyciele i uczniowie, wyznają ten sam system wartości, wynikający z wyznawania tej samej wiary. Widział $w$ niej szansę dla prawidlowego kształtowania postaw moralno-religijnych. Ciekawe jest też jego spojrzenie na problem koedukacji, który nie jest tak jednoznaczny, jak to jest dzisiaj oceniane.

Gdy dzisiaj toczy się dyskusja nad kształtem szkolnictwa i wychowania nowego pokolenia, powrót do idei wychowawczych Michała Klepacza jest bardzo słuszny. Zapewne pedagogika chrześcijańska reprezentowana przez tego wybitnego humanistę i pedagoga może mieć istotny wpływ na ksztalt myśli i praktyki pedagogicznej początku XXI wieku. Programy wychowania i system wartości obecne w twórczości pedagogicznej biskupa Michała Klepacza, nie straciły na swojej aktualności, a wprost przeciwnie nabrały nowego kształtu w obecnej sytuacji poszukiwania nowego modelu szkoły. Współpraca ze środowiskiem nauczycielskim i młodzieżowym wymaga wciąż doskonalenia zasad wspótżycia opartego na mocnym fundamencie wzajemnego poszanowania własnej autonomii, oraz możliwości wymiany wypracowanych teorii wychowawczych i działań dla dobra poszczególnych środowisk. Propozycja szkół katolickich nie jest formą dyskredytowania szkół świeckich, ale pokazaniem innego modelu wartości, na którym opiera się działalność pedagogiczną.

Bardzo przekonywująco znaczącą opinię wyrazil, w dziesięć lat po śmierci Biskupa Lódzkiego, Kardynał Stefan Wyszyński: „Biskup Michał Klepacz stał w otwartych drzwiach do nowych czasów"10.

\footnotetext{
${ }^{9}$ K. Gruczýski, op. cit., s. 74.

${ }^{10}$ Kard. Stefan Wyszyński, Slowo o biskupie Michale Klepaczu, w: W kierunku chrześcijaniskiej kultury, Warszawa 1978.
} 